\title{
Penerapan Empirical Best Linear Unbiased Prediction (EBLUP) pada Pendugaan Tingkat Pengangguran Terbuka Level Kecamatan di Provinsi Banten
} \author{
Sub-District Level in Banten Province) \\ Apriliansyah ${ }^{1 *}$, Ika Yuni Wulansari² \\ ${ }^{1,2}$ Politeknik Statistitka STIS \\ Jalan Otto Iskandardinata 64C, Kelurahan Bidaracina, Jakarta Timur \\ E-mail: 211709567@stis.ac.id
}

(Empirical Best Linear Unbiased Prediction (EBLUP) for Open Unemployment Rate Estimation at

\begin{abstract}
ABSTRAK
Pengangguran merupakan masalah yang kompleks baik disebabkan maupun memberikan dampak terhadap banyak faktor. Di Indonesia, indikator pengangguran diukur melalui tingkat pengangguran terbuka (TPT). Indikator ini dikumpulkan melalui Survei Angkatan Kerja Nasional (Sakernas). Banten merupakan provinsi dengan TPT tertinggi serta selalu masuk dalam lima besar TPT tertinggi di Indonesia sejak tahun 2016 hingga 2018. Sebagai upaya percepatan penurunan angka pengangguran, perlu adanya informasi sampai ke level terkecil. Namun, sampel yang digunakan oleh Sakernas tidak mencukupi untuk pendugaan TPT secara langsung. Tujuan dari penelitian ini adalah menghasilkan penduga tingkat pengangguran terbuka (TPT) level kecamatan dengan presisi yang lebih baik melalui Small Area Estimation (SAE). Metode SAE yang digunakan adalah Empirical Best Linear Unbiased Prediction (EBLUP). Data yang digunakan adalah indikator penyusun TPT dari Sakernas 2018 dan variabel penyerta yang berasal dari Podes 2018 Provinsi Banten. Hasil dari penelitian ini menunjukkan bahwa terdapat sepuluh variabel penyerta yang berkorelasi dengan TPT. Kemudian, nilai RRMSE menunjukkan bahwa EBLUP meningkatkan presisi pendugaan jika dibandingkan dengan penduga langsung. Terdapat dua kecamatan yang memiliki hasil TPT sangat tinggi yaitu kecamatan Curugbitung dan Koroncong. Hasil estimasi EBLUP pada TPT level kecamatan ini dapat digunakan oleh pemerintah daerah untuk menurunkan TPT secara lebih terfokus dan lebih tepat sasaran, utamanya pada kecamatan-kecamatan dengan TPT yang tinggi.
\end{abstract}

Kata kunci: SAE, EBLUP, RRMSE, TPT

\section{ABSTRACT}

Unemployment is a complex problem caused or affected for a lot of problems. In Indonesia, unemployment indicator measured by open unemployment rate. This indicator collected by National Labor Force Survey (Sakernas). Banten is a province with highest open unemployment rate number and also on a list of five highest number in Indonesia from 2016 to 2018. As a force to acceleration for dropping unemployment number, it needs an information until lower level for example district level. However, sample that used for Sakernas is not satisfied for direct estimating open unemployment rate. Purpose of this study is to obtain better subdistrict level of open unemployment rate estimator within Small Area Estimation (SAE). . Estimation that used is Empirical Best Linear Unbiased Prediction (EBLUP). Data that used is component indicator of open unemployment rate from Sakernas 2018 and auxiliary variable from Podes of Banten Province 2018. Result from this research show that there are ten auxiliary variable sources from PODES 2018, which are correlated with district level open unemployment rate of Banten Province in 2018. Then, RRMSE value showed that EBLUP have better precision than direct estimation. There are two districts that have highest category of open unemployment rate value which are Curugbitung, and Koroncong

Keywords: SAE, EBLUP, RRMSE, TPT

\section{PENDAHULUAN}

Menurut Bank Dunia (2018) Indonesia merupakan negara terbesar keempat didunia. BPS (2018) mencatat bahwa jumlah penduduk sebanyak sekitar 250 juta jiwa dan pertumbuhan penduduk sebesar $1.38 \%$. Jumlah penduduk tersebut diharapkan mampu menjadi salah satu modal dalam pembangunan ekonomi. Todaro (2011) menjelaskan bahwa pembangunan ekonomi merupakan proses multidimensional yang melibatkan banyak perubahan mendasar dalam struktur sosial dan masyarakat. Namun, jumlah penduduk yang terus bertambah juga dapat menjadi salah satu permasalahan suatu negara. Salah satu permasalahan yang timbul adalah tidak tersedianya lapangan pekerjaan bagi seluruh penduduk. Hal ini menyebabkan terlalu lebihnya penawaran tenaga kerja sedangkan permintaan yang tersedia terbatas. Ranis (2004) menjelaskan selisih antara permintaan dengan penawaran ini merupakan labor surplus economy. Fenomena ini selanjutnya menciptakan suatu 
permasalahan baru yang disebut dengan pengangguran. Salah satu tujuan dalam tujuan berkelanjutan global (SDG's) adalah kesempatan kerja yang produktif dan menyeluruh serta pekerjaan yang layak untuk semua. Pada target ini terdapat salah satu target yaitu pengentasan pengangguran dengan pencapaian pekerjaan yang produktif serta layak bagi semua kalangan. Dalam upaya pengentasan ini perlu adanya indikator yang menggambarkan pengangguran terlebih dahulu.

Di Indonesia indikator pengangguran diukur melalui angka Tingkat Pengangguran Terbuka (TPT). Pengangguran terbuka merupakan kondisi benar-benar tidak memiliki pekerjaan (Sukirno, 2010). Indikator tersebut dikumpulkan melalui suatu survei yaitu Survei Angkatan Kerja Nasional (SAKERNAS). Survei ini dilaksanakan dua kali setiap tahunnya yaitu pada bulan Februari yang dilakukan untuk menduga level provinsi serta bulan Agustus yang dilakukan untuk menduga level kabupaten/kota. Hal ini merupakan bukti keseriusan pemerintah dalam upaya pengentasan pengangguran terbuka. Pengentasan ini perlu dilakukan secara sinergis dari level nasional hingga ke level kecamatan. Namun, ketersediaan data hingga level kecamatan belum dapat terpenuhi dikarenakan kurangnya sampel dari setiap wilayah di kecamatan tersebut. Kerlinger (1973) menyebutkan bahwa hubungan antara jumlah sampel yang digunakan dengan besar kesalahan statistik yang dihasilkan berbanding terbalik sehingga jika sampel yang digunakan sedikit akan menghasilkan kesalahan yang besar. Hal ini menyebabkan statistik yang dihasilkan tidak presisi. Statistik yang dihasilkan dari pendugaan ini disebut dengan penduga langsung.

Permasalahan dari penduga langsung tersebut dapat diatasi dengan cara menggunakan metode penduga berbasis model atau disebut penduga tidak langsung. Metode penduga yang sering digunakan adalah metode Small Area Estimation (SAE). Rao (2003) menjelaskan bahwa SAE merupakan metode penduga yang meminjam kekuatan variabel penyerta untuk meningkatkan efektifitas dari ukuran sampel yang tersedia. Salah satu model SAE yang tersedia adalah menggunakan model dasar yaitu Empirical Best Linear Unbiased Predictor (EBLUP). Implementasi metode SAE pada estimasi pengangguran telah dilakukan di beberapa negara, diantaranya: Kim (2015) menerapkan SAE pada masalah riil survei angkatan kerja di Korea; Bertarelli, dkk. (2018) dan Marino, dkk. (2019) menerapkan SAE untuk memperkirakan pengangguran di Italia. Menurut Bertarelli, dkk. (2018) dan Marino, dkk. (2019), perkiraan langsung dari kejadian pengangguran di Italia tidak dapat dirilis karena banyak daerah di luar sampel, dan sebagian besar dicirikan oleh ukuran sampel yang kecil yang membuat perkiraan langsung tidak memadai. Mereka menyatakan bahwa prediktor terbaik empiris (EBLUP) mewakili alternatif berbasis model yang sesuai.

Secara umum, pada Agustus tahun 2018, tercatat bahwa pengangguran di Indonesia mencapai tujuh juta orang. Salah satu provinsi dengan jumlah penganggur terbanyak adalah provinsi Banten dengan angka TPT sebesar 8,52\% atau sekitar 8 hingga 9 orang dari 100 kelompok angkatan kerja berstatus menganggur. Jika ditelusuri, provinsi ini cenderung mengalami penurunan yang kurang signifikan dalam angka tersebut. BPS (2018) mencatat sejak tahun 2016 hingga 2018 Provinsi Banten selalu menjadi nomer pertama dalam tingginya angka TPT di Indonesia.

Dengan demikian, diperlukan statistik TPT pada domain yang lebih kecil (kecamatan) untuk pengambilan kebijakan yang lebih tepat sasaran seperti penentuan kecamatan prioritas yang merupakan kantong-kantong pengangguran di Provinsi Banten. Berdasarkan latar belakang tersebut, penelitian ini bertujuan menghitung TPT level kecamatan di Provinsi Banten tahun 2018 menggunakan SAE metode EBLUP. Hipotesis penelitian adalah TPT hasil pendugaan SAE metode EBLUP memberikan presisi yang lebih tinggi daripada hasil pendugaan langsung.

\section{METODE}

\section{Metode Pengumpulan Data}

Wilayah yang dijadikan sebagai lokus penelitian adalah seluruh kecamatan Provinsi Banten yaitu berjumlah 155 kecamatan. Seluruh data yang digunakan merupakan data sekunder yang berasal dari Sakernas Provinsi Banten periode Agustus tahun 2018 dan PODES Provinsi Banten tahun 2018. Piranti lunak yang digunakan pada penelitian ini adalah R-Studio dengan menggunakan package "SAE" serta Microsoft Excel.

\section{Metode Analisis}

\section{Small Area Estimation (SAE)}

Dedianto (2018) menjelaskan bahwa SAE merupakan metode penduga yang berbasis permodelan. Terdapat dua model yang dapat digunakan dalam model SAE yaitu model unit dan model area. Perbedaan yang mendasar dari kedua model ini adalah data pendukung yang digunakan. 
A. Model Level Area

Rao (2003) menjelaskan bahwa model level area merupakan model yang didasari dari ketersediaan data pendukung yang ada untuk tingkatan area tertentu. Model dasar yang digunakan pada penduga area yang dikenal sebagai Fay - Herriot adalah sebagai berikut

$$
\widehat{\theta_{l}}=\mathrm{x}_{i}^{T} \beta+\mathrm{v}_{\mathrm{i}}+\mathrm{e}_{i}
$$

dengan $\mathbf{x}_{i}^{\mathrm{T}}$ adalah vektor variabel penyerta yang tidak memiliki error, $\boldsymbol{\beta}$ adalah vektor parameter model, $z_{\mathrm{i}}$ adalah konstanta yang diketahui, $v_{\mathrm{i}}$ adalah pengaruh acak area kecil, dan $e_{\mathrm{i}}$ adalah sampling error.

B. Model Level Unit

Rao (2003) menjelaskan bahwa model level unit merupakan model yang didasari dari ketersediaan data pendukung yang ada untuk tingkatan unit tertentu yang merupakan responden survei. Model yang digunakan pada proses SAE berbasis unit adalah:

$$
y_{i j}=\mathrm{x}_{i j}^{T} \beta+\mathrm{v}_{i}+\mathrm{e}_{i j}
$$

dengan $\mathbf{x}_{\mathrm{ij}}{ }^{\mathrm{T}}$ adalah vektor variabel penyerta yang bersesuaian dengan individu ke- $j$ area ke- $i, \beta$ adalah vektor parameter model, $v_{\mathrm{i}}$ adalah pengaruh acak area kecil, dan $e_{\mathrm{ij}}$ adalah sampling error individu ke$j$ area ke- $i$.

\section{Empirical Best Linear Unbiased Predictor (EBLUP)}

Asumsi yang dikembangkan dari model SAE adalah peubah respon dijelaskan oleh hubungan keragaman yang disebut pengaruh tetap. Sedangkan, pengaruh acak dalam model area kecil tidak dapat diketahui oleh informasi tersebut. Gabungan dari kedua keragaman ini disebut sebagai model pengaruh campuran general linear mixed model (GLMM). GLMM merupakan model lanjutan dari model sederhana yaitu memasukkan unsur pengaruh acak kedalam model. Model level area merupakan pengembangan dari model GLMM. Model level area sederhana dinamakan model Fay-Herriot. Diketahui model Fay - Herriot adalah sebagai berikut

$$
\widehat{\theta_{l}}=\mathrm{x}_{i}^{T} \beta+\mathrm{v}_{\mathrm{i}}+\mathrm{e}_{i}
$$

dimana $e_{i}$ adalah sampling error pada area ke- $i$ yang diasumsikan diketahui dengan $\mathrm{e}_{i} \sim \mathrm{N}\left(0, \psi_{i}\right)$. Rao (2003) menjelaskan bahwa melalui proses penyelesaian generalized atau weighted least-square didapatkan penduga bagi $\widehat{\theta}_{\iota}$ dengan asumsi keragaman acak $\left(\sigma_{v}^{2}\right)$ diketahui adalah

$$
\widehat{\theta}_{l}^{B L U P}=\mathrm{x}_{i}^{T} \widehat{\beta}+\gamma_{i}\left(\widehat{\theta}_{l}-\mathrm{x}_{i}^{T} \widehat{\beta}\right)
$$

dengan nilai $\gamma_{i}=\frac{\sigma_{v}^{2}}{\sigma_{v}^{2}+\psi_{i}}$ dan nilai $\widehat{\beta}=\left(\sum_{i=1}^{m} \frac{\mathbf{x}_{\mathrm{i}} \mathbf{x}_{\mathrm{i}}^{\mathrm{T}}}{\left(\psi_{i}+\sigma_{v}^{2}\right)}\right)^{-1}\left(\sum_{i=1}^{m} \frac{\mathbf{x}_{i} \widehat{\theta}_{2}}{\left(\psi_{i}+\sigma_{v}^{2}\right)}\right)$. Namun, seringkali nilai $\sigma_{v}^{2}$ tidak diketahui sehingga perlu diduga menggunakan metode penduga tertentu seperti Restricted Maximum Likelihood (REML). Hasil dari penduga bagi $\widehat{\theta}_{l}$ menjadi

$$
\widehat{\theta}_{l}^{E B L U P}=\mathrm{x}_{i}^{T} \widehat{\beta}+\widehat{\gamma}_{l}\left(\widehat{\theta}_{l}-\mathrm{x}_{i}^{T} \widehat{\beta}\right)
$$

dengan nilai $\gamma_{i}=\frac{\widehat{\sigma_{v}^{2}}}{\widehat{\sigma_{v}^{2}+\psi_{i}}}$ dan nilai $\widehat{\beta}=\left(\sum_{i=1}^{m} \frac{\mathbf{x}_{\mathbf{i}} \mathbf{x}_{\mathrm{T}}^{\mathbf{T}}}{\left(\psi_{i}+\widehat{\sigma}_{v}^{2}\right)}\right)^{-1}\left(\sum_{i=1}^{m} \frac{\mathbf{x}_{i} \widehat{\theta}_{l}}{\left(\psi_{i}+\widehat{\sigma}_{v}^{2}\right)}\right)$. Nilai $\widehat{\sigma_{v}^{2}}$ adalah keragaman acak hasil pendugaan menggunakan REML.

\section{Mean Square Error (MSE)}

Rao (2003) menjelaskan bahwa kebaikan dari nilai penduga yang diperoleh dengan melihat nilai Mean Square Error (MSE) yang berasal dari penduga yang diperoleh. Andaikan penduga BLUP yang diperoleh adalah ${\widehat{\theta_{l}}}^{B L U P}$. Maka MSE dari penduga tersebut ditulis sebagai berikut: 


$$
\operatorname{MSE}\left({\widehat{\theta_{l}}}^{B L U P}\right)=g_{1 i}\left(\sigma_{v}^{2}\right)+g_{2 i}\left(\sigma_{v}^{2}\right)
$$

dimana $g_{1 i}\left(\sigma_{v}^{2}\right)=\frac{\sigma_{v}^{2} \psi_{i}}{\psi_{i}+\sigma_{v}^{2}}=\gamma_{i} \psi_{i}$ dan $g_{2 i}=\left(1-\psi_{i}\right)^{2} \mathbf{x}_{i}^{T}\left[\sum_{i=1}^{m} \frac{\mathbf{x}_{\mathbf{i}} \mathbf{x}_{i}^{\mathrm{T}}}{\left(\psi_{i}+\sigma_{v}^{2}\right)}\right]^{-1} \mathbf{x}_{i}$. Seperti yang telah dijelaskan sebelumnya bahwa nilai $\sigma_{v}^{2}$ tidak diketahui. MSE bagi EBLUP adalah (Amaliana, 2012).

$$
\operatorname{MSE}\left({\widehat{\theta_{l}}}^{E B L U P}\right)=g_{1 i}\left(\sigma_{v}^{2}\right)+g_{2 i}\left(\sigma_{v}^{2}\right)+2 g_{3 i}\left(\sigma_{v}^{2}\right)
$$

dimana $g_{3 i} \approx\left[\frac{\psi_{i}^{2}}{\left(\psi_{i}+\widehat{\sigma_{v}^{2}}\right)}\right]$ dan $\widehat{\sigma_{v}^{2}}$ yang digunakan merupakan penduga dengan metode pendugaan REML. Pada penelitian ini, setelah angka MSE diperoleh akan dibandingkan melalui suatu ukuran yang disebut Relative Root Mean Square Error (RRMSE). RRMSE dihitung dengan formula

$$
\operatorname{RRMSE}(\theta)=\frac{\sqrt{\operatorname{MSE}(\widehat{\theta})}}{\widehat{\theta}} \times 100 \%
$$

Rao (2003) menyatakan bahwa perbandingan yang dilakukan adalah membandingkan nilai RRMSE antar metode penduga yang digunakan dengan metode pendugaan langsung. Kriteria yang digunakan pada penelitian adalah jika nilai RRMSE penduga EBLUP dengan penduga REML lebih kecil daripada nilai RRMSE pendugaan langsung maka penduga EBLUP dikatakan lebih baik daripada penduga langsung.

\section{Tingkat Pengangguran Terbuka}

Seperti yang telah dijelaskan sebelumya bahwa indikator pengangguran di Indonesia di hitung dengan angka tingkat pengangguran terbuka. BPS (2018) menjelaskan bahwa tingkat pengangguran terbuka adalah persentase jumlah penganggur terhadap jumlah angkatan kerja. Penganggur yang dimaksud adalah orang yang tidak punya pekerjaan dan mencari pekerjaan atau mempersiapkan usaha atau tidak mencari pekerjaan serta orang yang sudah punya pekerjaan namun belum mulai bekerja (ILO,2018). Pada penelitian ini, indikator ini dihitung dengan formula

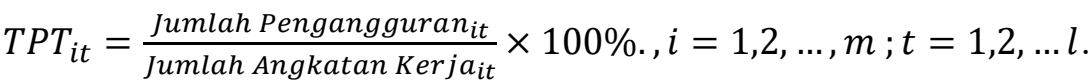

Dengan Jumlah Pengangguran $i t=$ Jumlah pengangguran wilayah ke- $i$ tahun ke- $t$ dan Jumlah Angkatan Kerja $a_{i t}=$ Jumlah angkatan kerja wilayah $-i$ tahun ke- $t$

\section{HASIL DAN PEMBAHASAN}

\section{Penduga Langsung Tingkat Pengangguran Terbuka}

Tabel 1. Hasil Penduga Langsung Seluruh Wilayah Tersampel

\begin{tabular}{cc}
\hline Statistik & Tingkat Pengangguran Terbuka \\
\hline Rata - rata & 9,575 \\
Varians & 767,776 \\
Minimum & 0 \\
Median & 7,5 \\
Maksimum & 71,4 \\
Total Amatan & 144 Kecamatan \\
\hline
\end{tabular}

Secara umum, Provinsi Banten memiliki 155 kecamatan yang tersebar di delapan kabupaten/kota. Pada penelitian ini, seluruh kecamatan dijadikan sebagai amatan penelitian. Namun, pada kegiatan Sakernas Agustus 2018 tidak semua kecamatan menjadi lokus pengambilan sampel. Terdapat sebelas kecamatan yang tidak masuk kedalam lokus sampel sehingga penduga langsung yang dapat dilakukan hanya pada 144 kecamatan. Merujuk pada Tabel 1, didapatkan bahwa nilai maksimum TPT yang diperoleh adalah sebesar $71,4 \%$ dengan nilai minimum sebesar $0 \%$. Dikarenakan data penduga langsung akan digunakan pada penduga tidak langsung SAE EBLUP maka data yang ada harus memiliki nilai varians tiap amatannya. Nilai maksimum dan minimum yang ada merupakan data yang tidak valid karena terdapat 38 kecamatan yang memiliki nilai varians sama dengan nol. Maka, sebanyak 49 kecamatan tidak akan diikut sertakan kedalam model. Berikut adalah ringkasan statistik setelah 49 kecamatan tidak diikut sertakan. 
Tabel 2. Hasil Penduga Langsung Seluruh Wilayah Valid

\begin{tabular}{cc}
\hline Statistik & Tingkat Pengangguran Terbuka \\
\hline Rata - rata & 8,9608 \\
Varians & 32,4593 \\
Minimum & 1,89 \\
Median & 7,675 \\
Maksimum & 27,56 \\
Total Amatan & 106 Kecamatan \\
\hline
\end{tabular}

Dari Tabel 2, diketahui bahwa dari 106 kecamatan yang valid memiliki rata - rata sebesar 8,9608\% atau sekitar 8 hingga 9 penduduk dari 100 angkatan kerja menganggur. Kemudian, nilai maksimum diperoleh kecamatan Pandeglang, kabupaten Pandeglang. Nilai minimum diperoleh kecamatan Malingping, kabupaten Lebak. Nilai maksimum dan rata - rata yang diperoleh seluruh kecamatan di Provinsi Banten lebih besar dari angka nasional yaitu $5,34 \%$.

\section{Penduga Tidak Langsung SAE EBLUP}

Setelah melakukan penduga langsung terhadap 106 kecamatan, selanjutnya akan dilakukan penduga tidak langsung berbasis model SAE EBLUP. Sebelum dilakukan permodelan, pemilihan variabel penyerta perlu dilakukan. Rao (2003) menjelaskan bahwa penduga tidak langsung berbasis model dilakukan dengan cara meminjam kekuatan area sekitar area kecil yang diamati dengan cara menggunakan variabel penyerta. Variabel penyerta yang ada berasal dari pengamatan yang tidak mengandung error seperti sensus atau registrasi wilayah. Pada penelitian ini variabel penyerta yang digunakan berasal dari pendataan Potensi Desa (PODES) Provinsi Banten tahun 2018. Variabel penyerta yang digunakan harus memiliki korelasi serta signifikan berkorelasi dengan variabel yang akan diduga. Dari 43 variabel penyerta yang digunakan terdapat 10 variabel penyerta yang berkorelasi. Berikut adalah nilai korelasi dan signifikansi korelasi 10 variabel penyerta terhadap variabel TPT.

Tabel 3. Korelasi dan Signifikansi Variabel Penyerta Terhadap Variabel TPT

\begin{tabular}{|c|c|c|c|c|}
\hline Nama Variabel & $\begin{array}{c}\text { Notasi } \\
\text { Variabel }\end{array}$ & $\mathrm{N}$ & Korelasi & Sig. \\
\hline Rasio Jumlah Keluarga PLN per 1000 Penduduk & $X_{1}$ & 106 & $-0,1950$ & 0,0450 \\
\hline Rasio Jumlah Sekolah Dasar (SD) per 100 Penduduk & $X_{2}$ & 106 & $-0,1920$ & 0,0490 \\
\hline Jumlah Kelompok Usaha Individu & $X_{11}$ & 106 & $-0,2110$ & 0,0300 \\
\hline Jumlah Tower BTS & $X_{16}$ & 106 & $-0,2150$ & 0,0270 \\
\hline Rasio Jumlah IMK Produksi Kayu per 100 Penduduk & $X_{19}$ & 106 & $-0,2250$ & 0,0490 \\
\hline Rasio Jumlah IMK Makanan per 100 Penduduk & $X_{24}$ & 106 & 0,2850 & 0,0030 \\
\hline Rasio Jumlah Desa Melakukan Pemb. TIK & $X_{28}$ & 106 & $-0,2680$ & 0,0060 \\
\hline Rasio Jumlah Desa Melakukan Pemb. Sanitasi & $X_{29}$ & 106 & $-0,2320$ & 0,0170 \\
\hline $\begin{array}{l}\text { Rasio Jumlah Desa Melakukan Pemberdayaan Pendidikan } \\
\text { Kesehatan dan Kebudayaan }\end{array}$ & $X_{34}$ & 106 & $-0,2300$ & 0,0180 \\
\hline Rasio Jumlah Desa Melakukan Pemberdayaan Transportasi & $X_{35}$ & 106 & $-0,2070$ & 0,0330 \\
\hline
\end{tabular}

Kemudian, seluruh variabel harus dijamin tidak berkorelasi satu dengan lainnya. Sehingga, perlu dicek menggunakan nilai Variance Inflation Factor (VIF) untuk pengujiannya. Ghozali (2009) menjelaskan bahwa kriteria variabel $\mathrm{ke}-\mathrm{i}$ tidak berkorelasi adalah ketika nilai VIF < 10. Diketahui, setelah melakukan pengujian VIF, seluruh variabel tidak ada yang memiliki nilai VIF lebih dari 10. Setelah mendapatkan variabel penyerta yang signifikan berkorelasi dilakukan pembentukan model penduga EBLUP - REML.

Pada tahap pertama, sepuluh variabel yang signifikan berkorelasi dimasukkan kedalam model. Didapatkan bahwa hanya variabel X24 yang signifikan pada taraf signifikansi 10\% pada model tahap pertama SAE EBLUP metode penduga REML. Proses yang selanjutnya dilakukan adalah melakukan seleksi variabel yang layak masuk model EBLUP dengan kriteria memiliki signifikansi mendekati satu serta tidak signifikan pada suatu taraf signifikansi. Model yang dipilih dari rangkaian proses tersebut adalah yang memiliki nilai Akaike Information Criteria (AIC) terkecil. Berikut adalah ringkasan dari nilai AIC serta variabel yang dikeluarkan disetiap tahap untuk metode EBLUP - REML. 
Tabel 4. Proses Pemilihan Model EBLUP - REML

\begin{tabular}{ccc}
\hline Tahap & Variabel & AIC \\
\hline 1 & $x_{1}, x_{2}, x_{11}, x_{16}, x_{19}, x_{24}, x_{28}, x_{29}, x_{34}, x_{35}$ & 667,9220 \\
2 & $x_{2}, x_{19}, x_{24}, x_{28}, x_{29}, x_{35}$ & 659,6666 \\
3 & $x_{19}, x_{24}, x_{28}, x_{29}$ & 656,9168 \\
4 & $x_{19}, x_{28}, x_{24}$ & 655,8312 \\
5 & $x_{28}, x_{24}$ & 656,5821 \\
\hline
\end{tabular}

Dari tabel 4 diatas diketahui bahwa model keempat memiliki AIC terkecil sehingga, model keempat akan digunakan sebagai model dari EBLUP - REML. Berikut adalah penduga koefisien regresi, dan koefisien keragaman acak area EBLUP - REML.

Tabel 5. Hasil penduga koefisien regresi dan koefisien keragaman acak area EBLUP - REML dengan AIC terkecil

\begin{tabular}{ccc}
\hline Variabel & $\hat{\beta}_{E B L U P-M L}$ & $\mathrm{p}$-value \\
\hline Intersep & 9,3466 & 0,0000 \\
$x_{19}$ & $-3,9780$ & 0,0532 \\
$x_{24}$ & 0,6119 & 0,0995 \\
$x_{28}$ & $-3,7264$ & 0,0243 \\
$\widehat{\sigma_{v}^{2}}$ & 19,0492 & - \\
\hline
\end{tabular}

Diketahui dari Tabel 5 diatas, variabel $x_{19}$ dan $x_{24}$ signifikan pada taraf signifikansi $10 \%$ sedangkan variabel $x_{28}$ signifikan pada taraf signifikansi $5 \%$. Berikut adalah ringkasan statistik dari hasil penduga $\widehat{\theta}_{l}$.

Tabel 6. Ringkasan hasil penduga tingkat pengangguran terbuka level kecamatan Provinsi Banten tahun 2018

\begin{tabular}{cc}
\hline Statistik & TPT EBLUP - REML \\
\hline Rata - rata & 8,4988 \\
Varians & 17,4932 \\
Minimum & 2,4721 \\
Median & 7,9727 \\
Maksimum & 25,6332 \\
\hline Total Amatan & 106 Kecamatan \\
\hline
\end{tabular}

\section{Perbandingan Hasil RRMSE}

Seperti yang telah dijelaskan sebelumnya bahwa kebaikan hasil pendugaan yang diperoleh dapat diukur melalui nilai RRMSE yang dihasilkan kemudian dibandingkan satu dengan lainnya. Berikut adalah ringkasan hasil RRMSE dari seluruh metode penduga baik metode penduga langsung maupun metode penduga tidak langsung.

Tabel 7. Ringkasan Hasil RRMSE Seluruh Metode Penduga

\begin{tabular}{ccc}
\hline Statistik & \multicolumn{2}{c}{ RRMSE } \\
\cline { 2 - 3 } & Penduga Langsung & EBLUP - REML \\
\hline Rata - rata & 40,2040 & 29,6930 \\
Minimum & 2,0530 & 2,0540 \\
Median & 35,8500 & 29,8430 \\
Maksimum & 108,4330 & 66,4170 \\
\hline Total Amatan & & 106 Kecamatan
\end{tabular}

Dari tabel 7, diketahui bahwa terjadi penurunan yang signifikan terhadap metode penduga langsung dengan metode penduga tidak langsung. Jika ditelusuri lebih dalam, model EBLUP REML memiliki rata-rata, nilai maksimum, nilai minimum serta median RRMSE yang lebih rendah daripada metode penduga langsung. Dapat dikatakan bahwa metode penduga menggunakan model EBLUP REML lebih presisi daripada penduga langsung. 


\section{Pengujian Normalitas Residual dan Pengaruh Acak Model EBLUP}

Asumsi yang harus dipenuhi pada model Fay-Herriot adalah asumsi kenormalan pada residual dan pengaruh acak yang dihasilkan dari model. Pengujian menggunakan uji kenormalan liliefors. Untuk pengaruh acak dari model EBLUP didapatkan $\mathrm{p}$ - value sebesar 0,057 dan untuk residual didapatkan $\mathrm{p}$ - value sebesar 0,2497. Kedua hasil tersebut lebih besar dari taraf signifikansi yaitu lima persen sehingga mendapatkan keputusan gagal tolak- $\mathrm{H}_{0}$. Dapat disimpulkan bahwa kedua komponen pengujian memenuhi asumsi pada model Fay-Herriot.

\section{Penduga Seluruh Wilayah Amatan Dengan Model Terbaik}

Diketahui bahwa terdapat 38 wilayah amatan yang tidak valid sehingga tidak diikutkan dalam analisis. Kemudian dilakukan pendugaan terhadap nilai TPT dari seluruh wilayah amatan tidak valid tersebut. Pendugaan menggunakan model terbaik yang telah didapatkan yaitu EBLUP REML. Hal ini disebut dengan pendugaan sintetik. Gonzales (1973) pada Rao (2003) menjelaskan bahwa suatu penduga dikatakan sintetik jika suatu penduga langsung yang reliable untuk area luas dengan asumsi bahwa area tersebut memiliki karakteristik yang sama seperti area yang luas. Berikut adalah deskriptif dari nilai TPT seluruh wilayah amatan kecamatan Provinsi Banten.

Tabel 8. Ringkasan hasil penduga tidak langsung (Metode EBLUP - REML) TPT level kecamatan Provinsi Banten tahun 2018

\begin{tabular}{cc}
\hline Statistik & Tingkat Pengangguran Terbuka \\
\hline Rata - rata & 8,7035 \\
Varians & 14,9751 \\
Minimum & 2,4960 \\
Median & 8,4883 \\
Maksimum & 25,6074 \\
\hline Total Amatan & 155 Kecamatan \\
\hline
\end{tabular}

Dari Tabel 8 di atas diketahui bahwa rata - rata tingkat pengangguran terbuka di Provinsi Banten mencapai 8,7035 persen atau dapat dikatakan sebanyak 8 hingga 9 dari 100 angkatan kerja di Provinsi Banten berstatus menganggur. Kemudian, nilai tertinggi diperoleh 25,6074 persen yaitu kecamatan Curugbitung sedangkan nilai terendah diperoleh kecamatan Kasemen dengan nilai sebesar 2,4960 persen. Berikut adalah peta tematik dari persebaran hasil estimasi EBLUP - REML.

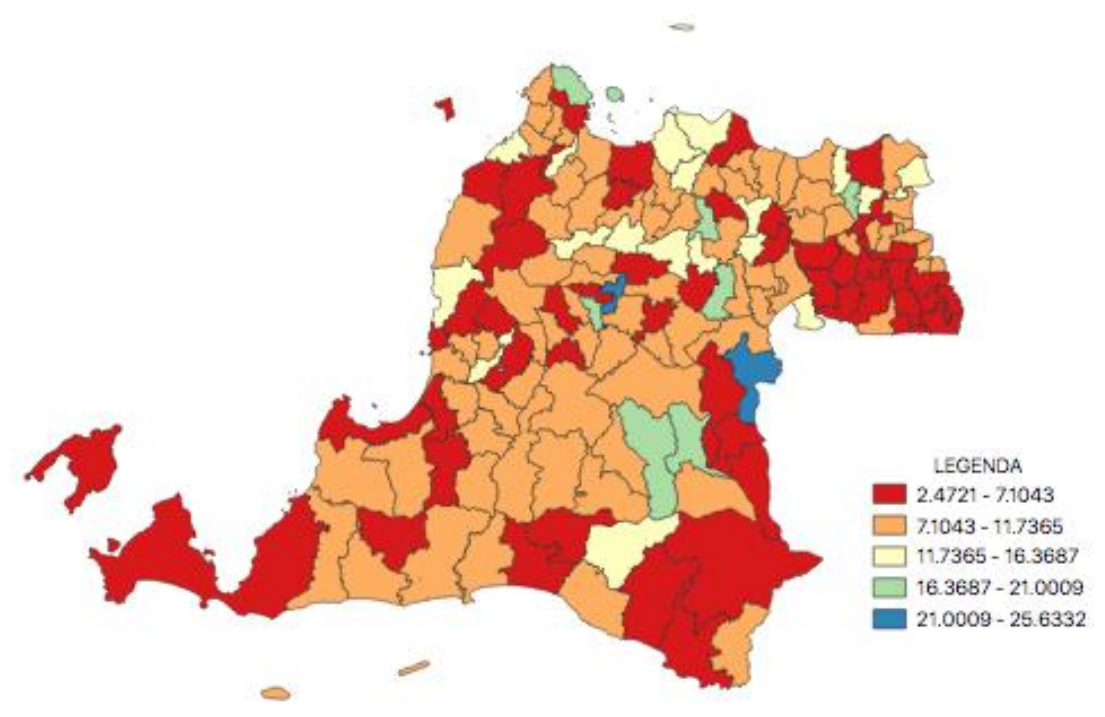

Gambar 1. Pemetaan hasil penduga tidak langsung (EBLUP - REML) TPT level kecamatan Provinsi Banten Tahun 2018

Dari Gambar 1, diketahui bahwa terdapat 52 kecamatan yang memiliki kategori pertama yang ditunjukkan dengan warna merah. Pada kategori pertama ini, terdapat 27 kecamatan yang berada dibawah angka TPT nasional yaitu sebesar 5.34 persen sehingga 25 kecamatan sudah berada diatas angka TPT nasional. Kemudian, pada kategori kedua diketahui bahwa terdapat 76 kecamatan yang ditunjukkan oleh warna jingga. Selanjutnya, 
kecamatan yang berada di kategori ketiga, yang ditujukkan dengan warna kuning, berjumlah sebanyak 18 kecamatan. Kecamatan yang berada di kategori keempat, yang ditunjukkan dengan warna hijau, berjumlah sebanyak 7 kecamatan. Kategori terakhir yang merupakan ketegori yang paling tertinggi berjumlah sebanyak 2 kecamatan. Secara keseluruhan, dari 155 kecamatan terdapat 128 kecamatan yang berada diatas angka TPT nasional.

\section{KESIMPULAN}

Dari penjelasan di atas, diketahui bahwa pendugaan menggunakan model EBLUP dengan metode estimasi REML memiliki hasil yang lebih presisi ditunjukkan oleh nilai RRMSE yang lebih rendah daripada nilai RRMSE penduga langsung sehingga model EBLUP REML merupakan model terbaik bagi penduga tidak langsung tingkat pengangguran terbuka level kecamatan Provinsi Banten tahun 2018. Saran bagi pemerintah Provinsi Banten adalah mempertimbangkan penggunaan metode estimasi tidak langsung dalam menduga angka TPT level kecamatan. Metode estimasi tidak langsung yang dapat digunakan adalah EBLUP - REML. Informasi tingkat kecamatan ini berguna dalam percepatan penurunan angka TPT level provinsi. Kemudian, dalam proses percepatan penurunan angka TPT level kecamatan, pemerintah dapat memprioritaskan wilayah yang berada pada kategori kelima, keempat, ketiga dan kedua. Pada peta yang ditunjukkan oleh Gambar 1 secara berturut-turut kategori tersebut ditunjukkan oleh warna biru, hijau, kuning serta jingga. Kecamatan yang berada pada kategori kelima adalah kecamatan Curugbitung dan Koroncong. Kedua kecamatan ini diharapkan menjadi prioritas pertama dalam penurunan angka TPT level kecamatan.

\section{DAFTAR PUSTAKA}

Amalia, L. (2012). Penaksiran Mean Square Error (MSE) Empirical Best Linier Unbiased Prediction (SEBLUP) pada Model Fay - Herriot [Skripsi]. Depok: Universitas Indonesia.

Amaliah, R. (2018). Pendugaan Area Kecil pada Tingkat Pengangguran Terbuka Menggunakan Model Fay Herriot Spasial [Skripsi]. Jakarta: Politeknik Statistika STIS.

Anggraeni, Y. D. I., \& Nugrahadi, T. (2019). Penerapan Empirical Best Linear Unbiased Prediction Fay Herriot (EBLUP FH) dan Spatial EBLUP FH Pada Data Transformasi Logaritma. In Seminar Nasional Official Statistics (Vol. 2019, No. 1, pp. 93-103).

Badan Pusat Statistik. (2017).Pedoman Pencacah Sakernas Februari 2017. Jakarta : Badan Pusat Statistik.

Badan Pusat Statistik. (2018). Statistik Potensi Desa Provinsi Banten tahun 2018. Jakarta : Badan Pusat Statistik.

Badan Pusat Statistik. (2018).Keadaan Angkatan Kerja di Indonesia Agustus 2018. Jakarta : Badan Pusat Statistik.

Bertarelli, G., Ranalli, G., Bartolucci, F., D’Alò, M., \& Solari, F. (2018). Small area estimation for unemployment using latent Markov models. Survey Methodol, 44(2), 167-192.

Dedianto, D. \& Wulansari, I. Y. (2018). Aplikasi Small Area Estimation (SAE) Metode Pseudo- EBLUP Pada Official Statistics di Indonesia Studi Kasus: Estimasi Pengeluaran Rumah Tangga di Provinsi Jawa Timur Tahun 2016. Jurnal Aplikasi Statistika dan Komputasi Statistik, 10(2), 33-38.

Guilford, J. P. (1956). Fundamental statistics in psychology and education (3rd ed.). McGraw-Hill.

Harsanti, R. (2006). Penerapan Metode Empirical Best Linear Unbiased Prediction pada Model Small Area Estimation dalam Pendugaan Tingkat Pengangguran di Kota Bogor [Skripsi]. Bogor: Institut Pertanian Bogor

Kim, J. K., Park, S., \& Kim, S. Y. (2015). Small area estimation combining information from several sources. Survey Methodology, 41(1), 21.

Kurniawan, R., Arifatin, D., Noviani, A., \& Fadhlullah, F. (2019). Evaluasi Pendugaan Angka Partisipasi Kasar Perguruan Tinggi Tahun 2018 dengan Small Area Estiomation Benchmarking. In Seminar Nasional Official Statistics (Vol. 2019, No. 1, pp. 67-73).

Mauliani, M., Maiyastri, M., \& Diana, R. (2019). Pendugaan Angka Pengangguran Di Kabupaten Padang Pariaman Menggunakan Small Area Estimation dengan Pendekatan Hierarchical Bayes (HB) Lognormal. Jurnal Matematika UNAND, 7(4), 15-21.

Marino, M. F., Ranalli, M. G., Salvati, N., \& Alfo, M. (2019). Semiparametric empirical best prediction for small area estimation of unemployment indicators. The Annals of Applied Statistics, 13(2), 1166-1197.

Rao JNK. (2003). Small area estimation. London: Wiley.

Razali, N. M., \& Wah, Y. B. (2011). Power comparisons of shapiro-wilk, kolmogorov-smirnov, lilliefors and anderson-darling tests. Journal of statistical modeling and analytics, 2(1), 21-33. 
Saei, A., \& Chambers, R. (2003). Small area estimation: A review of methods based on the application of mixed models.

Searle, S. R., Casella, G., \& McCulloch, C. E. (2009). Variance components (Vol. 391). John Wiley \& Sons.

Torabi, M. (2007). Some contributions to small area estimation [Disertasi]. Ottawa: Carleton University.

Wackerly, D., Mendenhall, W., \& Scheaffer, R. L. (2014). Mathematical statistics with applications. Cengage Learning.

Yanuar. 2009. Ekonomi Makro Suatu Analisis Untuk Konteks Indonesia. Jakarta : Yayasan Mpu Ajar Artha

Zaja, N., Yozza, H., \& Yanuar, F. (2019). Small Area Estimation dengan Pendekatan Empirical Bayes Berbasis Model Beta-Binomial untuk Menduga Angka Pengangguran Di Sumatera Barat. Jurnal Matematika UNAND, 8(1), 120-127 